\title{
Efficacy of some Egyptian native plant extracts against Haemonchus contortus in vitro and in experimentally infected sheep along with the associated haematological and biochemical alterations
}

\author{
Noha M. F. Hassan ${ }^{1 *} \mathbb{D}$, Ahmed A. Zaghawa², Nadia M. T. Abu-Elezz ${ }^{1}$, Mohamed A. Nayel² and Akram A. Salama²
}

\begin{abstract}
Background: Haemonchosis is a serious disease affecting ruminants' productivity worldwide. Medicinal plants are deemed one of the most natural bio-products safely used as alternatives to the synthetic anthelmintics. In the present study, comparative efficacy of crude ethanolic extracts (CEEs) of Artemisia herba-alba (A. herba-alba), Balanites aegyptiaca (B. aegyptiaca) and Allium sativum (A. sativum) as alternative treatments was tested on Haemonchus contortus ( H. contortus). An in vitro test to evaluate the anthelmintic efficacy of various concentrations of extracts at 25, 30 and $50 \mathrm{mg} / \mathrm{ml}$ was accomplished on motility and viability of adult worms in comparison with albendazole, reference drug at $10 \mu \mathrm{g} / \mathrm{ml}$ at various time intervals. An in vivo test was carried out in lambs experimentally infected with $\mathrm{H}$. contortus to detect anthelmintic activity of CEES of A. herba-alba and B. aegyptiaca compared to albendazole. Fifteen parasitefree Baladi Egyptian lambs aged 4-8 months old were categorized into five groups, each of three lambs as follows: G1 was kept as uninfected untreated one, G2 was utilized as infected untreated group, G3 was given CEE of A. herba-alba, G4 was received CEE of $B$. aegyptiaca, and $\mathrm{G} 5$ was treated with albendazole.
\end{abstract}

Results: The in vitro test revealed that CEE of B. aegyptiaca had the most significant anthelmintic activity on adult $H$. contortus followed by A. herba-alba, while A. sativum was of the lowest effect. The in vivo test showed that the CEE of $B$. aegyptiaca achieved an excellent faecal egg reduction (100\%) at the 7th day post-treatment. The most efficient treatments that improved the haematological parameters and regained the level of serum total protein, albumin and A/G ratio, serum globulin, SGoT, SGPT, urea and creatinine to the almost normal levels were CEE of B. aegyptiaca, albendazole and CEE of A. herba-alba, respectively.

Conclusions: This study highlighted the marked anthelmintic potency of the CEEs of B. aegyptiaca and A. herba-alba on $\mathrm{H}$. contortus and the superiority of CEE of B. aegyptiaca as a talented anti-parasitic medicinal plant for sheep.

Keywords: Haemonchus contortus, Sheep, Artemisia herba-alba, Balanites aegyptiaca, Allium sativum, Haematological and biochemical changes

\footnotetext{
*Correspondence: nohamhassan555@yahoo.com

1 Department of Parasitology and Animal Diseases, National Research

Centre (NRC), 33 Bohouth Street, P.O. Box: 12622, Dokki, Giza, Egypt

Full list of author information is available at the end of the article
}

\section{Background}

Baladi sheep are accounted as beneficial and valuable food animals reared all over rural Egypt (Hanelein and Abdellatif 2003; El-Dakhly et al. 2012). Helminthiasis is deemed a great constraint against small ruminants 
husbandry (El-Ashram et al. 2017). Haemonchosis is one of the most serious widespread, infectious life threaten that negatively affected the livestock performance and productivity (Brik et al. 2019; Hassan et al. 2020). The blood-sucking barber pole worm, $H$. contortus, is the causative agent of the disease and considers the most critical and pathogenic abomasal nematode affecting ruminants worldwide including Egypt (Hassan et al. 2019; Arsenopoulos et al. 2021). The average daily blood loss in infected sheep is about $0.03 \mathrm{ml} /$ parasite (Awad et al. 2016). The infection causes pronounced effects in animal health involving mainly anaemia, inappetence to off-food and death in acute infection in particular young animals (Mannan et al. 2017). For decades, chemotherapeutics were utilized substantially to control parasitic diseases in ruminants. The excessive and inappropriate use of the anthelmintic drugs for prolonged period has resulted in the development of multi-drug-resistant gastrointestinal nematodes (GINs) (Shalaby 2013). Moreover, the risks of drug residues in food animal and the cost-effectiveness of the anthelmintics have motivated to seek about potent alternatives for sustainable parasitic control (Albadawi 2010). It was documented that the first helminth that developed the multi-drug resistance was $H$. contortus against various anthelmintic classes, particularly benzimidazole, levamisole and the macrocyclic lactone (Kebede 2019). Direct life cycle besides the high egg-laying rate of $H$. contortus is considered the main biological factor that could facilitate anthelmintic resistance to occur (Coles 2005). Medicinal plants containing promising bioactive constituents afford significant economic and environmentally acceptable solutions against parasitic infection in animals (Torres-Acosta et al. 2012). A. herba-alba plant, known also as desert worm wood (in Arabic as shih), is one of the family Asteraceae and commonly utilized in folk medicine and has various anti-parasitic impacts (Idris et al. 1982; Ahmed et al. 2020). B. aegyptiaca Del. (L.) (Family: Balanitaceae) is recognized as "desert date"; the fruits are utilized traditionally in the treatment of parasitic infection, gastrointestinal disturbance, syphilis and fever (Doughari et al. 2007; Vijigiri and Sharma 2010). Furthermore, $A$. sativum or garlic has been documented as potent natural agents against parasitism and fungal infection and reported as immuno-stimulant compound (Duke 2002; Orengo et al. 2016). Thus, the current study is designed to firstly investigate the comparative in vitro potency of crude ethanolic extracts of $A$. herba-alba, B. aegyptiaca and A. sativum. Moreover, it aims to use the most effcient extracts in vivo, as alternative treatments for haemonchosis among sheep.

\section{Methods}

Plants

Whole plant (stem and leaves) of $A$. herba-alba, B. aegyptiaca fruits and cloves of $A$. sativum were brought from local markets in Cairo Governorate, Egypt. The plant materials were identified at the laboratory of Medicinal and Aromatic Plants Research Department, National Research Center, then cleaned, shade-dried and mechanically ground utilizing a laboratory mortar and pestle. The ethanolic extracts were prepared according to Harborne (1984) as follows: the plant materials were pounded and then extracted with $70 \%$ ethanol. Plant materials were macerated at room temperature in dark place, and the percolate was collected by filtering through cotton wool. The process of maceration/ percolation was repeated three times for 3 weeks. The combined filtrate was completely evaporated in a vacuum rotary evaporator (Heidolph-Germany) under pressure at $50{ }^{\circ} \mathrm{C}$ to obtain a semi-solid crude ethanolic extract. The extract was scraped off, transferred to container, and kept airtight; it was stored at $4{ }^{\circ} \mathrm{C}$ until further use.

\section{Parasite}

Adult $H$. contortus worms were freshly assembled from abomasa collected from abattoir. The worms were thoroughly washed utilizing phosphate-buffered saline to remove debris and mucus (Soulsby 1986).

\section{In vitro bio-assay}

For the assessment of in vitro anthelmintic impacts of the crude ethanolic extract prepared from the three plants on adult $H$. contortus, the worm motility inhibition assay was achieved.

Twelve adult $H$. contortus worms were exposed separately to CEEs of $A$. herba-alba, B. aegyptiaca and $A$. sati$v u m$ at three various concentrations 25,30 and $50 \mathrm{mg} / \mathrm{ml}$ dissolved in DMSO (0.1\%). Albendazole was employed at $10 \mathrm{ug} / \mathrm{ml}$ as the standard drug (The Egyptian Company for Chemicals and Pharmaceuticals (ADWIA) 10th of Ramadan City). DMSO (0.1\%) was utilized as negative control. Three replicates were applied for each treatment. The worms' vitality was watched through detection complete inactivity and mortality at $0,2,4,6$ and $8 \mathrm{~h}$ of intervals. After $8 \mathrm{~h}$, the revival of the worm motility was tested as the extracts and albendazole were removed away and parasites were dropped again in PBS for $30 \mathrm{~min}$. Per cent worm motility inhibition (\% WMI) was assigned according to Rabel et al. (1994) by the following formula: 
$\%$ WMI $=\frac{(\text { Number of mobile worms in negative control Petri dish }- \text { Number of mobile worms in treatment Petridish }) \times 100}{(\text { Number of mobile worms in negative controls Petri dish })}$.

The mortality index was estimated as mentioned by Tariq et al. (2009) by the following formula:

$$
\begin{aligned}
& \text { Mortality index (MI) } \\
& =\frac{\text { Total number of immobile worms (dead) }}{\text { Total number of worms per Petri dish }} .
\end{aligned}
$$

\section{In vivo bioassay}

Animals

Seventeen Baladi lambs of 15-18 kg BW were bought from a private farm at Monieb, Giza Governorate. the manufacture company. Each lamb in groups 2 to 5 was infected by giving $10,000 \mathrm{~L}_{3}$ orally, at zero day of experiment. The treatment regimes were started 3 weeks post-infection. Blood samples were taken every 3 weeks till the end of the experiment, with EDTA for determination of haematological parameters and without anticoagulant for serum separation for assigning some significant biochemical parameters. Individual anal faecal samples were assembled for faecal egg counting by McMaster technique.

Faecal egg count reduction per cent (FECR \%) was estimated utilizing the formula reported by Tariq et al. (2009) as follows:

$$
\text { FECR\% }=\frac{\text { Pre-treatment egg count per gram }- \text { Post-treatment egg count per gram }}{\text { Pre-treatment egg count per gram }} .
$$

\section{Larval donors}

Two worm-free lambs were utilized as $H$. contortus larval donors. Larval culture was carried out according to Solusby (1986). The female adult worms of $H$. contortus were used freshly and disintegrated for liberation of eggs. The culture was obtained by addition of sand charcoal, sterilized faeces and few drops of water. Daily mixing is required for aeration with maintaining of humidity for 12 days. Then, infective larvae were harvested and counted. Each lamb was infected using 10.000 third-stage larvae $\mathrm{L}_{3}$. Three weeks post-infection, faecal samples were confirmed positive for $H$. contortus using concentration floatation technique. Donors' faecal samples were used as source of monospecific $H$. contortus infective larvae for further infection.

\section{Experimental animals}

A total of fifteen Baladi lambs of about 4-8 months old were employed. Lambs were clinically and parasitologically examined to confirm the absence of infection. The animals were categorized into five groups, each of three lambs. Group 1 was kept as uninfected untreated one. Group 2 was utilized as infected untreated group. Group 3 was given a single dose of CEE of $A$. herbaalba $2 \mathrm{~g} / \mathrm{kg}$ BW followed by booster dose after 12 days (Tariq et al. 2009). Group 4 was received $3 \mathrm{~g} / \mathrm{kg}$ BW orally of CEE of $B$. aegyptiaca for 3 successive days (Koko et al. 2000). Group 5 was treated with a single dose of albendazole $(0.5 \mathrm{~g} / 20 \mathrm{~kg} \mathrm{BW})$ as described by

\section{Statistical analysis}

Data are presented as mean \pm standard error. Differences between means in the different groups were tested for significance by one-way analysis of variance (ANOVA) and Duncan's multiple range tests to detect the significance among means in between different experimental groups and weeks (Snedecore and Cochran 1984). SPSS (version 16) computer program was used.

\section{Results}

\section{In vitro bioassay}

The three used plant extracts exhibited anthelmintic potency on the adult worms in comparison with the negative control (DMSO 0.1\%). There was a concentrationdependent effect on adult $H$. contortus worms. In other words, CEE of A. herba-alba, B. aegyptiaca and A. sati$\nu u m$ at $50 \mathrm{mg} / \mathrm{ml}$ was the most effective concentration. The CEE of B. aegyptiaca revealed the fastest and greatest anthelmintic affectivity in comparison with the other extracts at the same concentration in terms of mortality/ paralysis of the worms. It was noticed that the motility of the worms diminished gradually from the start of experiment especially, in treatment with CEEs of $A$. herba-alba, $B$. aegyptiaca and $A$. sativum at $50 \mathrm{mg} / \mathrm{ml}$ concentration, whereas the worms which revealed motility $8 \mathrm{~h}$ post-exposure were $3 \pm 0.57,3 \pm 1.0$ and $5.33 \pm 0.88$, respectively. After the re-suspension in PBS for $30 \mathrm{~min}$, the worms which re-attained their motility were $2 \pm 1.1$, $1 \pm 0.57$ and $3 \pm 1.15$, respectively (Table 1 ). The mean \%WMI was of 81.8, 90.9 and 72.7, and the MI was of 0.83 , 0.91 and 0.75 , respectively (Table 2 ). 


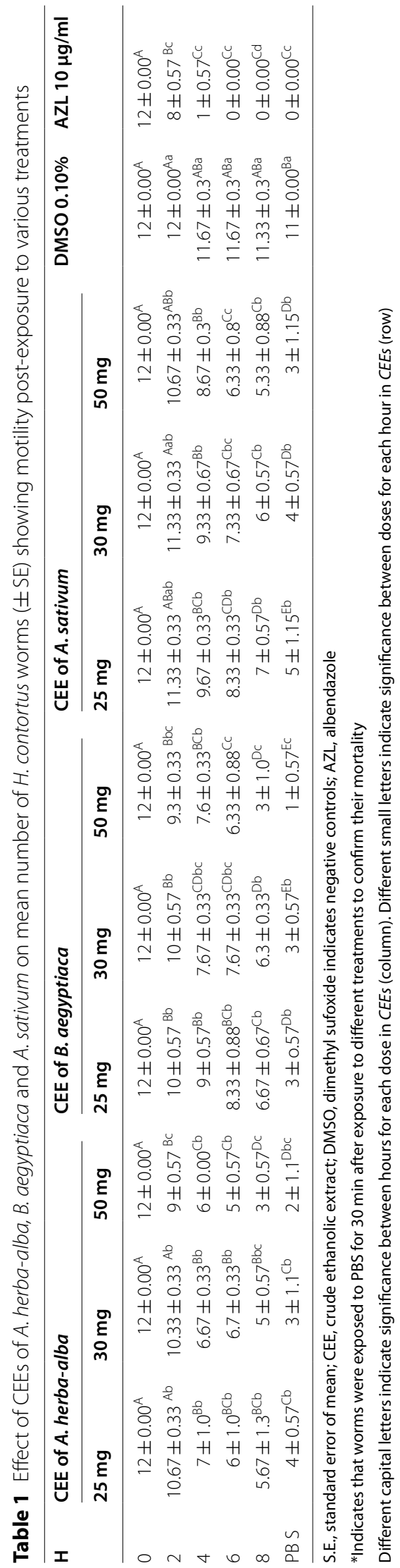


Table 2 Mean percent of worm motility inhibition and mortality index of different CEE-treated worms at various treatments

\begin{tabular}{|c|c|c|c|c|c|c|c|c|c|}
\hline & \multicolumn{9}{|c|}{ CEE concentration } \\
\hline & \multicolumn{3}{|c|}{ A. herba-alba } & \multicolumn{3}{|c|}{ B. aegyptiaca } & \multicolumn{3}{|l|}{ A. sativum } \\
\hline & $25 \mathrm{mg} / \mathrm{ml}$ & $30 \mathrm{mg} / \mathrm{ml}$ & $50 \mathrm{mg} / \mathrm{ml}$ & $25 \mathrm{mg} / \mathrm{ml}$ & $30 \mathrm{mg} / \mathrm{ml}$ & $50 \mathrm{mg} / \mathrm{ml}$ & $25 \mathrm{mg} / \mathrm{ml}$ & $30 \mathrm{mg} / \mathrm{ml}$ & $50 \mathrm{mg} / \mathrm{ml}$ \\
\hline WMI\% & 63.6 & 72.7 & 81.8 & 72.7 & 72.7 & 90.9 & 54.5 & 63.6 & 72.7 \\
\hline Ml & 0.67 & 0.75 & 0.83 & 0.75 & 0.75 & 0.91 & 0.58 & 0.67 & 0.75 \\
\hline
\end{tabular}

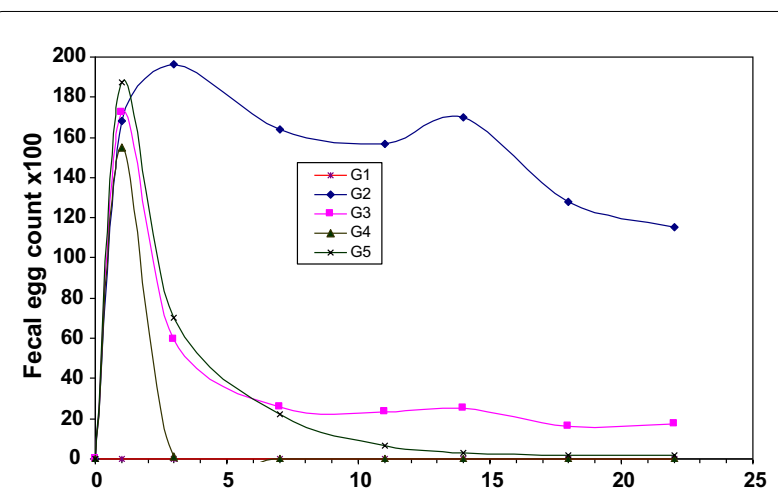

Fig. 1 Mean faecal egg counts for different sheep groups under experiment; infected untreated (G1), A. herba-alba (G2), B. aegyptiaca (G3) compared to albendazole one (G4)

Table 3 The FECR\% recorded in G1 (uninfected untreated), G2 (infected untreated), G3 (A. herba-alba), G4 (B. aegyptiaca) versus G5 (albendazole) at different days post-treatment

\begin{tabular}{llclll}
\hline $\begin{array}{l}\text { Days post- } \\
\text { treatment }\end{array}$ & FECR\% & & & & \\
\cline { 2 - 6 } & G1 (\%) & G2 (\%) & G3 (\%) & G4 (\%) & G5 (\%) \\
\hline 3 & 0 & -17.0 & 65.5 & 99.0 & 62.6 \\
7 & 0 & 2.57 & 85.1 & 100 & 88.1 \\
14 & 0 & -1.2 & 85.4 & 100 & 98.6 \\
22 & 0 & 3.97 & 89.9 & 100 & 99.1 \\
\hline
\end{tabular}

\section{In vivo experiment}

The infection was detected for all lambs groups except uninfected untreated group at 21 days post-infection by detecting $H$. contortus eggs in faeces through faecal examinations. The results of preclinical in vitro experiment revealed a low potency of anthelmintic effect of $A$. sativum CEE on $H$. contortus adult worms. So, the in vivo study concerned on the evaluation of anthelmintic activity of CEE of $A$. herba-alba, B. aegyptiaca compared to albendazole in the experimentally $H$. contortus-infected lambs. A significant reduction has been detected in the mean FECs for G4 (B. aegyptiaca CEE) and G5 (albendazole-treated) followed by G3 (A. herba-alba CEE) compared to G2 (infected untreated) 3 days post-treatment
(PT) till the end of the experiment. The FECs of G3, G4 and G5 at 3 days PT were $59.3 \pm 3.5,1.5 \pm 0.28$ and $70.17 \pm 5.4$, respectively, while FEC of the infected untreated one was $196.7 \pm 41$ as demonstrated in Fig. 1 . The CEE of B. aegyptiaca (G4) has recorded 99\% FECR at 3 days PT. At the 7 th day PT, the FECR was $100 \%$. The effect of CEE of $A$. herba-alba and albendazole on the FECR was comparable as illustrated in Table 3.

\section{Haematological parameters}

Significant variations in haematological values among groups were detected. The experimental infection with haemonchosis caused a decrease in RBCs count, $\mathrm{Hb}$ g/ $\mathrm{dL}$ and $\mathrm{PCV} \%$ in all the groups. Moreover, it gave arise to increment of WBCs and eosinophil levels in all the groups compared to uninfected untreated one. The control infected untreated group recorded the lowest RBCs count, $\mathrm{Hb}$ g/dL and PCV\% and highest WBCs and eosinophil levels compared to uninfected untreated one which was within the normal range in the whole experimental period. The result revealed that the most efficient treatments of haemonchosis in sheep, which improve the RBCs count, $\mathrm{Hb}$ concentration and $\mathrm{PCV} \%$ and cause a gradual decrease in WBCs and eosinophil levels to return it to almost normal level, were recorded in the groups treated with $B$. aegyptiaca CEE, albendazole and $A$. herba-alba CEE successively (Table 4).

\section{Biochemical parameters}

The results declared that the experimental infection of lambs with haemonchosis induced a decrease in total protein, albumin levels, serum globulin and albumin/ globulin $(\mathrm{A} / \mathrm{G})$ ratio in all the groups. Moreover, it causes a higher level of SGOT, SGPT, BUN and creatinine level compared to the uninfected untreated one. The control infected untreated group showed the lowest level of the total protein, albumin levels, albumin/globulin and (A/G) ratio besides high level of SGOT, SGPT, BUN and creatinine level compared to the uninfected untreated one. The results revealed that the most efficient treatments that improved total protein, albumin levels, A/G ratio, level of SGOT, SGPT and BUN to almost the normal level were 
Table 4 Effect of various treatments on haematological parameters of different experimental lamb groups

\begin{tabular}{|c|c|c|c|c|c|c|}
\hline \multirow[t]{2}{*}{ Parameter } & \multirow[t]{2}{*}{ Week } & \multicolumn{5}{|c|}{ Experimental animals } \\
\hline & & G1 & G2 & G3 & G4 & G5 \\
\hline \multirow[t]{4}{*}{ RBC s count $\left(10^{6} / \mu \mathrm{l}\right)$} & 0 & $9.05 \pm 0.10^{\mathrm{Dab}}$ & $9.4 \pm 0.41^{\text {Aab }}$ & $8.7 \pm 0.26^{A b}$ & $9.5 \pm 0.24 \mathrm{Aab}$ & $9.9 \pm 0.52^{\mathrm{Aa}}$ \\
\hline & 3 & $9.2 \pm 0.14^{\mathrm{CDa}}$ & $5.3 \pm 0.21^{\mathrm{Bb}}$ & $5.0 \pm 0.36^{\mathrm{Eb}}$ & $5.2 \pm 0.10^{\mathrm{Cb}}$ & $5.4 \pm 0.29^{\mathrm{Cb}}$ \\
\hline & 6 & $10.2 \pm 0.26^{\mathrm{ABa}}$ & $4.0 \pm 0.45^{\mathrm{Cd}}$ & $5.8 \pm 0.44^{\mathrm{CDEC}}$ & $9.2 \pm 0.21^{\mathrm{ABa}}$ & $7.1 \pm 0.44^{\mathrm{Bb}}$ \\
\hline & 9 & $7.4 \pm 0.10^{B C}$ & $9.93 \pm 0.19^{\mathrm{Aa}}$ & $9.0 \pm 0.12^{\mathrm{Ab}}$ & $4.3 \pm 0.44 \mathrm{~B}^{\mathrm{Cd}}$ & $10.2 \pm 0.26^{\mathrm{ABa}}$ \\
\hline \multirow[t]{4}{*}{$\mathrm{Hb}(\mathrm{g} / \mathrm{d})$} & 0 & $10.6 \pm 0.68^{\mathrm{Abc}}$ & $11.3 \pm 0.23^{\mathrm{Aab}}$ & $10.6 \pm 0.32^{\mathrm{Abc}}$ & $9.6 \pm 0.31^{C D C}$ & $12.0 \pm 0.14^{\mathrm{Aa}}$ \\
\hline & 3 & $11.5 \pm 0.60^{\mathrm{Aa}}$ & $7.3 \pm 0.43^{\mathrm{Bb}}$ & $6.9 \pm 0.39^{\mathrm{cb}}$ & $7.1 \pm 0.17^{\mathrm{Eb}}$ & $7.7 \pm 0.44^{\mathrm{Eb}}$ \\
\hline & 6 & $11.2 \pm 0.36^{\mathrm{Aa}}$ & $5.1 \pm 0.16^{\mathrm{Cd}}$ & $10.17 \pm 0.08^{\mathrm{Ab}}$ & $10.4 \pm 0.30^{\mathrm{BCb}}$ & $8.2 \pm 0.20^{\mathrm{CDEC}}$ \\
\hline & 9 & $11.27 \pm 0.43^{\mathrm{Aa}}$ & $5.26 \pm 0.37^{\mathrm{Cc}}$ & $9.8 \pm 0.16^{\mathrm{ABb}}$ & $11.5 \pm 0.16^{\mathrm{Aa}}$ & $9.1 \pm 0.15^{\mathrm{Bb}}$ \\
\hline \multirow[t]{4}{*}{ PCV\% } & 0 & $28.28 \pm 0.51^{\mathrm{Cb}}$ & $28.57 \pm 0.32^{\mathrm{Ab}}$ & $30.0 \pm 0.08^{\mathrm{Aa}}$ & $29.0 \pm 0.18^{\mathrm{ABa} b}$ & $28.8 \pm 0.61^{\mathrm{Aab}}$ \\
\hline & 3 & ${ }^{\mathrm{Ca}} 29.05 \pm 0.22^{\mathrm{AB}}$ & $18.45 \pm 0.32^{\mathrm{Bbc}}$ & ${ }^{b} 18.59 \pm 0.58^{D}$ & $17.2 \pm 0.24^{\mathrm{Fc}}$ & $18.4 \pm 0.41^{\mathrm{Dbc}}$ \\
\hline & 6 & $29.8 \pm 0.43^{\mathrm{ABa}}$ & $14.7 \pm 0.63^{D c}$ & $25.0 \pm 0.32^{\mathrm{Bb}}$ & $26.16 \pm 0.53^{\mathrm{CDb}}$ & $25.6 \pm 0.60^{\mathrm{Bb}}$ \\
\hline & 9 & $28.8 \pm 0.36^{\mathrm{BCb}}$ & $15.6 \pm 0.91^{\mathrm{CD} c d}$ & $25.59 \pm 0.31^{B C}$ & $30.78 \pm 0.22^{\mathrm{Aa}}$ & $26.5 \pm 0.22^{B C}$ \\
\hline \multirow[t]{4}{*}{ WBCs count $\left(10^{3} / \mu \mathrm{l}\right)$} & 0 & $12.0 \pm 0.08^{\mathrm{Ba}}$ & $12.6 \pm 0.49^{\mathrm{Ba}}$ & $12.3 \pm 0.51^{\mathrm{DEa}}$ & $12 \pm 0.49^{\mathrm{Ea}}$ & $12.0 \pm 0.14^{\mathrm{Aa}}$ \\
\hline & 3 & $18.1 \pm 1.4^{\text {Aab }}$ & $16.2 \pm 0.55^{\mathrm{Ab}}$ & $19.3 \pm 1.1^{\mathrm{Aa}}$ & $18.0 \pm 0.69^{\mathrm{BCab}}$ & $12.0 \pm 0.26^{A c}$ \\
\hline & 6 & $12.6 \pm 0.68^{\mathrm{Bbc}}$ & $10.7 \pm 0.40^{c c}$ & $13.3 \pm 0.55 C^{D b}$ & $17.8 \pm 0.86^{\mathrm{BCa}}$ & $12.3 \pm 0.45^{\mathrm{Abc}}$ \\
\hline & 9 & $11.0 \pm 1.1^{\mathrm{Bbc}}$ & $9.4 \pm 0.34^{\complement c}$ & $10.4 \pm 0.20^{\mathrm{Ebc}}$ & $15.4 \pm 0.72^{\mathrm{Da}}$ & $11.9 \pm 0.20^{\mathrm{Ab}}$ \\
\hline \multirow[t]{4}{*}{ Eosinophil $\left(10^{3} / \mu l\right)$} & 0 & $0.6 \pm 0.66^{\mathrm{Ba}}$ & $0.3 \pm 0.33^{\mathrm{BCa}}$ & $0.3 \pm 0.33^{\mathrm{Ca}}$ & $0 \pm 0.00^{\mathrm{Da}}$ & $0.67 \pm 0.33^{\mathrm{AB}}$ \\
\hline & 3 & $7.3 \pm 2.8^{\mathrm{Aa}}$ & $4.7 \pm 0.88^{\mathrm{Aa}}$ & $5.3 \pm 0.33^{\mathrm{Aa}}$ & $5.6 \pm 0.88^{\mathrm{ABa}}$ & $0 \pm 0.00^{\mathrm{Bb}}$ \\
\hline & 6 & $0.3 \pm 0.3^{B b}$ & $0.33 \pm 0.33^{\mathrm{BCb}}$ & $0.67 \pm 0.33^{\mathrm{BCb}}$ & $3.67 \pm 1.2^{\mathrm{BCa}}$ & $0.67 \pm 0.33^{\mathrm{ABb}}$ \\
\hline & 9 & $1.3 \pm 0.3^{\mathrm{Bab}}$ & $0 \pm 0.00^{\mathrm{Cb}}$ & $0.67 \pm 0.67^{\mathrm{BCab}}$ & $2.3 \pm 0.88^{\mathrm{CDa}}$ & $0.33 \pm 0.33^{\mathrm{ABb}}$ \\
\hline
\end{tabular}

G, lambs group

Capital letters: means within the same column of different letters are significantly different at $(P<0.01)$. Small letters: means within the same row of different letters are significantly different at $(P<0.01)$

B. aegyptiaca CEE, albendazole and $A$. herba-alba CEE, respectively (Table 5).

\section{Discussion}

Haemonchus contortus infection is an urgent disease among ruminants. Herbal medicine has global offered safe, economic and effective products of anthelmintic properties. This study was firstly implemented to assess the comparative in vitro anthelmintic potency of crude ethanolic extracts of native Egyptian medicinal plants, namely $A$. herba-alba, $B$. aegyptiaca and $A$. sativum, versus the standard drug albendazole. After that, it aims to in vivo test the most talented plant extracts among sheep experimentally infected with $H$. contortus as alternative era of treatment. The three tested plant extracts provided an in vitro anthelmintic and a concentration-dependent effect on the adult $H$. contortus worms compared with negative controls and drug standard group. They had an inhibitory effect on the motility and viability of the adult worms. The CEE of B. aegyptiaca was of the greatest per cent of WMI and MI followed by A. herba-alba and A. sativum. Similarly, previous finding confirmed that a potent in vitro effect on the motility and vitality of $H$. contortus adult worms through using various plant species had been reported Artemisia absinthium (Tariq et al. 2009), Cissus quadrangularis L and Schinus molle L. (Zenebe et al. 2017) and Punica granatum (Hassan et al. 2020).

The study evoked the significant in vivo anthelmintic impact of CEEs of $A$. herba-alba, B. aegyptiaca in comparison with albendazole on lambs experimentally infected with $H$. contortus. A marked reduction in FECs after 3 days PT and continued throughout the experimental period was recorded in the group treated with CEE of $B$. aegyptiaca followed by $A$. herba-alba CEE-treated one. A great FECR (100\% and $85.1 \%$ ) was recorded for CEE of $B$. aegyptiaca and A. herba-alba, respectively, at the 7th day PT till the end of the experiment, while albendazole caused $88.1 \%$ FECR. These results agree with the results reported by Idris et al. (1982) who proved a successful impact of $A$. herba-alba on goat infected with haemonchosis; El-Ghazaly et al. (1997) who concluded that $B$. aegyptiaca had antischistosomicidal effect; and Koko et al. (2000) who observed the curative effect of $B$. aegyptiaca on liver fasciolosis. Furthermore, Jaheed et al. (2019) documented a potent anthelmintic activity of $B$. aegyptiaca ethanolic extract where FECR reached $88.10 \%$ on 4th week PT. 
Table 5 Effect of various treatments on biochemical parameters of different experimental lamb groups

\begin{tabular}{|c|c|c|c|c|c|c|}
\hline \multirow[t]{2}{*}{ Parameter } & \multirow[t]{2}{*}{ Week } & \multicolumn{5}{|c|}{ Experimental animals } \\
\hline & & G1 & G2 & G3 & G4 & G5 \\
\hline \multirow[t]{4}{*}{ Serum total protein } & 0 & $7.03 \pm .23^{\mathrm{Aab}}$ & $6.53 \pm 0.26^{\mathrm{Bb}}$ & $6.97 \pm 0.23^{\mathrm{Aab}}$ & $7.5 \pm 0.14^{\mathrm{Aa}}$ & $6.53 \pm 0.26^{\mathrm{ABb}}$ \\
\hline & 3 & $5.87 \pm .067^{\mathrm{Ba}}$ & $6.43 \pm 0.23^{\mathrm{Ba}}$ & $4.9 \pm 0.14^{\mathrm{Cb}}$ & $4.47 \pm 0.37^{\mathrm{Cb}}$ & $5 \pm 0.36^{\mathrm{Db}}$ \\
\hline & 6 & $7.03 \pm .23^{\mathrm{Aab}}$ & $6.53 \pm 0.26^{\mathrm{Bb}}$ & $6.97 \pm 0.23^{\mathrm{Aab}}$ & $7.5 \pm 0.14^{\mathrm{Aa}}$ & $6.53 \pm 0.26^{\mathrm{ABb}}$ \\
\hline & 9 & $4.9 \pm .057^{D c}$ & $7.53 \pm .14^{\mathrm{Aa}}$ & $6.9 \pm 0.20^{\mathrm{Ab}}$ & $7 \pm 0.10^{\mathrm{Aab}}$ & $6.87 \pm 0.29 \mathrm{ABb}$ \\
\hline \multirow[t]{4}{*}{ Serum albumin } & 0 & $3.8 \pm 0.23^{\mathrm{Aa}}$ & $3.5 \pm 0.26^{\mathrm{Ba}}$ & $3.7 \pm 0.26^{\mathrm{ABa}}$ & $3.9 \pm 0.088^{\mathrm{ABa}}$ & $4.1 \pm 0.32^{\mathrm{Aa}}$ \\
\hline & 3 & $2.57 \pm 0.17^{\mathrm{Bb}}$ & $4.47 \pm 0.35^{\mathrm{ABa}}$ & $1.9 \pm 0.08^{\mathrm{Cbc}}$ & $2.0 \pm 0.13^{\mathrm{Cbc}}$ & $1.9 \pm 0.10^{\mathrm{cc}}$ \\
\hline & 6 & $1.73 \pm 0.12^{\mathrm{Db}}$ & $4.1 \pm 0.17^{\mathrm{ABa}}$ & $3.97 \pm 0.088^{\mathrm{Aa}}$ & $4.07 \pm 0.14^{\mathrm{ABa}}$ & $4.17 \pm 0.088^{\mathrm{Aa}}$ \\
\hline & 9 & $1.8 \pm 0.033^{\mathrm{Db}}$ & $4.77 \pm 0.26^{\mathrm{Aa}}$ & $4.37 \pm 0.21^{\mathrm{Aa}}$ & $4.47 \pm 0.37^{\mathrm{Aa}}$ & $4.2 \pm 0.20^{\mathrm{Aa}}$ \\
\hline \multirow[t]{4}{*}{ A/G ratio } & 0 & $1.2 \pm 0.20^{\mathrm{Aa}}$ & $1.2 \pm 0.31^{\mathrm{Aa}}$ & $1.2 \pm 0.18^{\mathrm{Aa}}$ & $1.09 \pm 0.00 \mathrm{ABa}$ & $1.8 \pm 0.44^{\mathrm{Aa}}$ \\
\hline & 3 & $0.79 \pm 0.11^{\mathrm{Bb}}$ & $2.6 \pm 0.68^{\mathrm{Aa}}$ & $0.64 \pm 0.05^{\mathrm{Ab}}$ & $0.90 \pm 0.20^{\mathrm{Bb}}$ & $0.63 \pm 0.09^{\mathrm{Bb}}$ \\
\hline & 6 & $0.53 \pm 0.04^{\mathrm{Bb}}$ & $1.5 \pm 0.23^{\mathrm{Aa}}$ & $1.4 \pm 0.12^{\mathrm{Aa}}$ & $1.5 \pm 0.22^{\mathrm{ABa}}$ & $1.8 \pm 0.19^{\mathrm{Aa}}$ \\
\hline & 9 & $0.59 \pm 0.02^{\mathrm{Bb}}$ & $1.8 \pm 0.36^{\mathrm{Aa}}$ & $1.8 \pm 0.32^{\mathrm{Aa}}$ & $1.8 \pm 0.43^{\mathrm{Aa}}$ & $1.6 \pm 0.31^{\mathrm{Aa}}$ \\
\hline \multirow[t]{4}{*}{ SGOT } & 0 & $11.07 \pm 0.38^{\mathrm{Da}}$ & $12.73 \pm 2.14^{\mathrm{Aa}}$ & $12.57 \pm 1.18^{\mathrm{Ba}}$ & $12.53 \pm 1.92^{\mathrm{Ba}}$ & $11.50 \pm 0.52^{\mathrm{Ba}}$ \\
\hline & 3 & $13.00 \pm 0.23^{\mathrm{Cab}}$ & $11.97 \pm 1.27^{\mathrm{Ab}}$ & $15.93 \pm 1.56^{\mathrm{Aa}}$ & $15.73 \pm 1.4^{\mathrm{Aab}}$ & $13.73 \pm 0.66^{\mathrm{Aab}}$ \\
\hline & 6 & $16.60 \pm 0.35^{\mathrm{Aa}}$ & $11.73 \pm 0.26^{\mathrm{Abc}}$ & $11.43 \pm 0.23^{\mathrm{Bbc}}$ & $10.87 \pm 0.35^{B C}$ & $12.50 \pm 0.50^{\mathrm{ABb}}$ \\
\hline & 9 & $13.60 \pm 0.32^{\mathrm{BCa}}$ & $11.63 \pm 0.69^{\mathrm{Ab}}$ & $11.57 \pm 0.40^{\mathrm{Bb}}$ & $10.70 \pm 0.20^{\mathrm{Bb}}$ & $11.83 \pm 0.12^{\mathrm{Bb}}$ \\
\hline \multirow[t]{4}{*}{ SGPT } & 0 & $24.6 \pm 4.4^{\mathrm{Ba}}$ & $31.4 \pm 11.9^{\mathrm{Aa}}$ & $25 \pm 1.8^{\mathrm{Ca}}$ & $28.97 \pm 4.7^{\mathrm{Ba}}$ & $33.4 \pm 2.5^{\mathrm{Ba}}$ \\
\hline & 3 & $42.8 \pm 7.7^{\mathrm{Aab}}$ & $30.1 \pm 9.8^{\mathrm{Ab}}$ & $47.7 \pm 6.17^{\mathrm{Aab}}$ & $54.23 \pm 4.0^{\mathrm{Aa}}$ & $56.2 \pm 4.1^{\mathrm{Aa}}$ \\
\hline & 6 & $43.3 \pm 3.6^{\mathrm{Aa}}$ & $32.4 \pm 9.4^{\mathrm{Aa}}$ & $32 \pm 3.30^{\mathrm{BCa}}$ & $28.7 \pm 5.8^{\mathrm{Ba}}$ & $34.4 \pm 1.2^{\mathrm{Ba}}$ \\
\hline & 9 & $40.7 \pm 0.93^{\mathrm{ABa}}$ & $29.6 \pm 9.2^{\mathrm{Aa}}$ & $27.4 \pm 1.43^{\mathrm{Ca}}$ & $28.27 \pm 4.9^{\mathrm{Ba}}$ & $33.6 \pm 5.0^{\mathrm{Ba}}$ \\
\hline \multirow[t]{4}{*}{ BUN } & 0 & $15.47 \pm 2.0^{\mathrm{Ca}}$ & $13.1 \pm 1.10^{\mathrm{Aa}}$ & $14.1 \pm 1.9^{\mathrm{Aa}}$ & $13.57 \pm 1.2^{\mathrm{Ba}}$ & $15.3 \pm 1.4^{\mathrm{BCa}}$ \\
\hline & 3 & $18.1 \pm 2.26^{\mathrm{BCa}}$ & $11.2 \pm 0.23^{\mathrm{Bb}}$ & $17.6 \pm 2.0^{\mathrm{Aa}}$ & $17.3 \pm 0.75^{\mathrm{Aa}}$ & $19.9 \pm 1.2^{\mathrm{Aa}}$ \\
\hline & 6 & $21.5 \pm 0.36^{\mathrm{ABa}}$ & $10.8 \pm 0.47^{B C}$ & $15.0 \pm 0.86^{\mathrm{Ab}}$ & $10.7 \pm 0.12^{\mathrm{Dc}}$ & $15.6 \pm 0.26^{\mathrm{BCb}}$ \\
\hline & 9 & $23.47 \pm 0.87^{\mathrm{Aa}}$ & $11.0 \pm 0.31^{\mathrm{BC}}$ & $14.37 \pm 1.09^{\mathrm{Ab}}$ & $10.9 \pm 0.26^{C D C}$ & $13.7 \pm 0.79^{\mathrm{cb}}$ \\
\hline \multirow[t]{4}{*}{ Serum creatinine } & 0 & $0.95 \pm 0.08^{\mathrm{Ca}}$ & $1.0 \pm 0.16^{\mathrm{ABa}}$ & $1.07 \pm 0.08^{\mathrm{Ba}}$ & $1.1 \pm 0.10^{\mathrm{Ca}}$ & $1.2 \pm 0.03^{\mathrm{BCa}}$ \\
\hline & 3 & $1.8 \pm 0.05^{\mathrm{Ba}}$ & $0.93 \pm 0.06^{B C}$ & $1.6 \pm 0.05^{\mathrm{Aab}}$ & $1.5 \pm 0.06^{\mathrm{Ab}}$ & $1.5 \pm 0.07^{\mathrm{Ab}}$ \\
\hline & 6 & $2.1 \pm 0.35^{\mathrm{ABa}}$ & $1.27 \pm 0.06^{\mathrm{Ab}}$ & $1.1 \pm 0.05^{\mathrm{Bb}}$ & $1.1 \pm 0.12^{\mathrm{BCb}}$ & $1.0 \pm 0.06^{\mathrm{Db}}$ \\
\hline & 9 & $1.8 \pm 0.05^{\mathrm{Ba}}$ & $1.06 \pm 0.12^{\mathrm{ABb}}$ & $1.0 \pm 0.04^{\mathrm{Bb}}$ & $1.0 \pm 0.09^{\mathrm{Cb}}$ & $1.0 \pm 0.06^{\mathrm{Db}}$ \\
\hline
\end{tabular}

G, lambs group

Capital letters: means within the same column of different letters are significantly different at $(P<0.01)$. Small letters: means within the same row of different letters are significantly different at $(P<0.01)$

The potent anthelmintic activity of the used ethanolic extracts might be related to the fact that alcohol-soluble active anthelmintic phyto-components had easy, efficient and rapid transcuticular absorption in the body of the worms due to the lipid-soluble nature of the ethanolic extracts (Eguale et al. 2007; Tariq et al. 2008). Moreover, Chothani and Vaghasiya (2011) reported that $B$. aegyptiaca contained very important bio-components including saponins, flavonoids, terpenoids, and phenolic. Besides, Meda et al. (2010) recorded significant antioxidant properties of $B$. aegyptiaca. The anti-parasitic affectivity of these phytochemical constituents had been also reported by Al-Shaibani et al. (2008) and Wang et al. (2010). It was mentioned that worm wood is also a rich source of various bioactive constituents, e.g. polyphenols, flavonoids and condensed tannins that had anti-parasitic effect (Mohamed et al. 2010; Akkari et al. 2014). In the present study, the CEE of $A$. sativum showed the lowest in vitro anthelmintic effect compared to the other used extracts. This acceptable anthelmintic activity might be attributed to the characteristic sulphur compounds in garlic (Itakura et al. 2001). Moreover, Chung (2006) documented antioxidant properties of garlic compounds due to the presence of alliin, an alkyl derivative of cysteine alkyl sulfoxide, allyl disulfide and allicin. A gradual improvement in $\mathrm{RBCs}$ count, $\mathrm{Hb} \mathrm{g} / \mathrm{dL}$ and $\mathrm{PCV} \%$ in CEE of B. aegyptiaca, albendazole, and CEE of $A$. herbaalba-treated groups, respectively, was disclosed in comparison with the infected untreated group. These results coincided with Koko et al. (2000), Khalid et al. (2005), 
Albadawi (2010) and Parmar et al. (2019). Meanwhile, these might be disagreed with that obtained by Bordoloi et al. (2012) who concluded that PCV per cent remained constant between $H$. contortus-infected and uninfected control group of lambs. The findings of the present study revealed that there was a significant decrease in $\mathrm{Hb}$ value, PCV\% and RBCs counts, in sheep infected with $H$. contortus due to the blood-sucking activities of the developing larval and young adults of $H$. contortus. The parasite secretes cathepsin L-like cysteine proteases that could potentially assist the helminths access to the host blood (Rhoads and Fetterer 1995).

Although the infection induced elevation of the WBCs count and eosinophils level, the used treatments CEE of B. aegyptiaca, albendazole and CEE of A. herba-alba had successes to return the values to their normal extent (Koko et al. 2000; Albadawi 2010; Hassan et al. 2013; Parmar et al. 2019). Oeosinophilia is well recognized in $H$. contortus-infected sheep, as a mean of protection (Huang and Appleton 2016).

Moreover, the biochemical analysis of the experimentally infected sheep showed a significant decrease in total serum protein with a consequent decrease in serum albumin and the A/G ratio (Soulsby 1986; Bahrami et al. 2011; Khan et al. 2012; Parmar et al. 2019).

In the current study, the infected untreated group showed a higher level of serum GOT/AST, GPT/ALT, serum urea and creatinine level (Bordoloi et al. 2012. It documented that in muscle atrophy and diseases without liver damage, ALT is elevated. Plasma AST is also increased with both muscle and liver damage (Allen and Randell 1993). Furthermore, Al-Zubaidy et al. (1987) deduced that traumatic damage to the lining of abomasal mucosa due to 4th-stage larvae and adult $H$. contortus caused high level of serum ALT and AST. The most significant and efficient treatments which improved serum GOT/AST, GPT/ALT, serum urea and creatinine level to be returned to almost normal level were the CEE of $B$. aegyptiaca and the CEE of $A$. herba-alba, respectively. So the used extracts were quite efficient to improve the animal health conditions; these more or less resemble that obtained by Idris et al. (1982) and Bordoloi et al. (2012).

\section{Conclusions}

It could be concluded that the in vitro anthelmintic activity assay declared the successful anthelmintic effect of CEEs of $B$. aegyptiaca, A. herba-alba and A. sativum compared to albendazole on $H$. contortus. The in vivo test exposed that the CEE of B. aegyptiaca was the most effective followed by CEE of $A$. herba-alba in competing the infection and improving the animal health conditions. It is suggested that the CEEs of B. aegyptiaca and $A$. herba-alba might have liver and kidney protective effects and could be considered as unique alternative treatments to avoid or delay the anthelmintic drug resistance in ruminants.

\section{Abbreviations}

A. herba-alba: Artemisia herba-alba; B. aegyptiaca: Balanites aegyptiaca; A. sativum: Allium sativum; CEE: Crude ethanolic extract; BUN: Blood urea nitrogen.

\section{Acknowledgements}

The authors duly acknowledge the support and technical help offered from the Parasitology and Animal diseases Department, Veterinary branch, National Research Centre, and deeply appreciate the support of Prof. Dr. Hala Abou Zeina.

\section{Authors' contributions}

AZ, NMTA and MN designed, supervised and directed the experiment. NMFH prepared the plant extracts. NMFH, NMTA, MN and AS carried out the in vivo and in vitro experiment. NMFH, AZ, NMTA, MN and AS analysed and discussed the resultant data. NMFH edited the manuscript. NMFH revised and reviewed the manuscript for publication. All authors read and approved the final manuscript.

\section{Funding}

This work was financially supported by the National Research Centre as a part of the project No.11020303-the 11th research plan. We deeply appreciate the technical and financial support offered for covering the cost of feed and animal keeping and care, presented by Prof. Dr. Hala Abou Zeina to accomplish this study.

Availability of data and materials

All data and material are available inside the manuscript.

\section{Declarations}

\section{Ethics approval and consent to participate}

The experiments were conducted in compliance with the requirements and recommendations of the Ethical Committee of the National Research Centre and the current Egyptian Law and Regulations that are assigned for the protection of the experimental animals to minimize the negative states (harms) and improve feeding and housing conditions under code number (16229). All authors read and approved the final manuscript. We had obtained written informed consent to use the animals in our study from the owner(s) of the animals. After the experiment had ended, owners of the Baladi lambs had regained the used animals.

\section{Consent for publication}

Not applicable.

\section{Competing interests}

The authors declare that they have no competing interests.

\section{Author details}

${ }^{1}$ Department of Parasitology and Animal Diseases, National Research Centre (NRC), 33 Bohouth Street, P.O. Box: 12622, Dokki, Giza, Egypt. ²Department of Animal Medicine and Infectious Diseases, Faculty of Veterinary Medicine, University of Sadat City, Menoufia 32897, Egypt.

Received: 16 July 2021 Accepted: 9 October 2021

Published online: 30 October 2021

\section{References}

Ahmed AH, Ejo M, Feyera T, Regassa D, Mummed B, Huluka SA (2020) In vitro anthelmintic activity of crude extracts of Artemisia herba-alba and Punica granatum against Haemonchus contortus. J Parasitol Res. https://doi.org/10.1155/2020/4950196 
Akkari H, Rtibi K, B'chir F, Rekik M, Darghouth MA, Gharbi M (2014) In vitro evidence that the pastoral Artemisia campestris species exerts an anthelmintic effect on Haemonchus contortus from sheep. Vet Res Commun 38:249-255. https://doi.org/10.1007/s11259-014-9609

AL Shaibani IRM, Phulan MS, Arijoand A, Qureshi TA (2008) Ovicidal and larvicidal properties of adhatoda vasica (I.) extracts against gastrointestinal nematodes of sheep in vitro. Pak Vet J 28(79):83

Albadawi ROE (2010) In vivo and in vitro anthelmintic activity of Balanites aegyptiaca and Artemisia herba Alba on Haemonchus contortus of sheep. PhD thesis Faculty of Veterinary Science University of Khartoum

Allen JG, Randell AG (1993) The clinical biochemistry of experimentally produced lupinosis in the sheep. Aust Vet J 70:283. https://doi.org/10. 1111/j.1751-0813.1993.tb07975

Al-Zubaidy AJ, Altaif Kl, Al-Qaisy HHK, Makkawi TA (1987) Gross pathology and histopathology of haemonchosis in sheep and goats in Iraq. Vet Parasitol 23:249-256

Arsenopoulos KV, Fthenakis GC, Katsarou El, Papadopoulos E (2021) Haemonchosis: a challenging parasitic infection of sheep and goats. Animals 11:363. https://doi.org/10.3390/ani11020363

Awad AH, Ali AM, Hadree DH (2016) Some haematological and biochemical parameters assessments in sheep infection by Haemonchus contortus. Tikrit J Pure Sci. 21:11-15

Bahrami AM, Doosti A, Noorian AM, Mousavi AB, Mousavi SGh, Modarreskia R, M., (2011) A study of plant extraction effect on experimental infected goats with Haemonchus contortus. J Med Sci 11:39-45. https://doi.org/10. 3923/jms.2011.39.45

Bordoloi G, Jas R, Ghosh JD (2012) Changes in the haemato-biochemical pattern due to experimentally induced haemonchosis in Sahabadi sheep. Parasit Dis 36:101-105. https://doi.org/10.1007/s12639-011-0079-7

Brik K, Hassouni T, Elkharrim K, Belghyti D (2019) A survey of Haemonchus contortus parasite of sheep from Gharb plain. Morocco. Parasite Epidemiol Control 4:e00094. https://doi.org/10.1016/j.parepi.2019.e00094

Chothani DL, Vaghasiya HU (2011) A review on Balanites aegyptiaca Del (desert date): phytochemical constituents, traditional uses and pharmacological activity. Pharmacogn Rev 5:55-62. https://doi.org/10.4103/0973-7847. 79100

Chung LY (2006) The antioxidant properties of garlic compounds: allyl cysteine, alliin, allicin, and allyl disulfide. J Med Food 9:205-213. https:// doi.org/10.1089/jmf.2006.9.205

Coles GC (2005) Anthelmintic resistance looking to the future: a UK perspective. Res Vet Sci 78:99-108. https://doi.org/10.1016/j.rvsc.2004.09.001

Doughari JH, Elmahmood AM, Manzara S (2007) Studies on the antibacterial activity of root extracts of Carica papaya L. Afr J Microbiol Res 1(3):037-041

Duke JA (2002) Handbook of medicinal herbs. CRC Press, Boca Raton

Eguale T, Tilahunb G, Debellac A, Feleked A, Makonnene E (2007) Haemonchus contortus: in vitro and in vivo anthelmintic activity of aqueous and hydroalcoholic extracts of Hedera helix. Exp Parasitol 116:340-345. https://doi. org/10.1016/j.exppara.2007.01.019

El-Ashram S, Alnasr I, Mehmood R, Hu M, He L, Suo X (2017) Haemonchus contortus and ovine host: a retrospective review. Int J Adv Res 5:972-999

El-Dakhly KM, Abo El-Hadid SM, El Askalany MA, Yanai T (2012) An abattoirbased study on helminths of slaughtered sheep in Beni-Suef, Egypt. Beni-Suef Univ J Appl Sci 1:49-60

El-Ghazaly GB, El-Tohami MS, El-Egam AB, AbdAlla WS, Mohamed MG (1997) Medicinal plants of the Sudan, part IV: medicinal plants of Northen Kordofan Omdorman, Islamic University Press, Khartoum, Sudan

Hanelein GFW, Abdellatif MA (2003) Trends in small ruminants husbandry and nutrition and specific response to Egypt. Small Ruminant Res 15:185-200. https://doi.org/10.1016/j.smallrumres.2003.08.011

Harborne JB (1984) Phytochemical methods, 2nd edn. Chapman and Hall, New York

Hassan MFM, Gammaz HA, Abdel-Daim MM (2013) Efficacy and safety of albendazole against Haemonchus Contortus infestation in goats. Res Zool 3:31-37. https://doi.org/10.5923/j.zoology.20130301.05

Hassan NMF, Aboelsoued D, Farag TK, Hassan S, Abu El Ezz NMT (2019) Assessment of Haemonchus contortus larval and adult somatic antigens in sero-diagnosis of haemonchosis in naturally infected sheep and goats. J Parasit Dis 43:718-725. https://doi.org/10.1007/s12639-019-01152-0

Hassan NMF, Sedky D, Abd El-Aziz TH, Shalaby HA, Abou-Zeina HAA (2020) Anthelmintic potency and curative effect of pomegranate peels ethanolic extract against Haemonchus contortus infection in goats. Int J Vet Sci 9:210-216. https://doi.org/10.37422/IJVS/20.002

Huang L, Appleton JA (2016) Eosinophils in helminth infection: defenders and dupes. Trends Parasitol 32:798-807. https://doi.org/10.1016/j.pt.2016.05. 004

Idris UE, Adam SE, Tartour G (1982) The anthelmintic efficacy of Artemisia herba-alba against Haemonchus contortus infection in goats. Natl Inst Anim Health Q 22:138-143

Itakura YM, Ichikawa Y, Mori R, Okino M, Udayama T, Morita T (2001) How to distinguish garlic from the other Allium vegetables. J Nutr 131:963S-967S. https://doi.org/10.1093/jn/131.3.963S

Jaheed E, Mohamed AH, Hassan NMF, Mahran KMA, Nasr SM, Abou-Zeina HAA (2019) Evaluation of the curative effect of Balanites aegyptiaca fruits ethanolic extract on Haemonchosis experimentally induced in Egyptian Baladi goats: phytoanalytical, parasitological and hematological studies. J Parasit Dis 43:638-650. https://doi.org/10.1007/s12639-019-01143-1

Kebede A (2019) Review on anthelmintic drug resistance nematodes and its methods of detection in Ethiopia. J Vet Med Animal Sci 2:1013

Khalid SMA, Amin MR, Mostofa M, Choudhury ME, Uddin B (2005) Effect of indigenous medicinal plants (Neem and Pineapple) against gastrointestinal nematodiasis in sheep. Int J Pharmacol 1:185-189. https://doi.org/ 10.3923/ijp

Khan FA, Sahoo A, Sonawane GG, Karim SA, Dhakad S, Pareek AK, Tripathi BN (2012) Effect of dietary protein on responses of lambs to repeated Haemonchus contortus infection. Livest Sci 150:143-151. https://doi.org/ 10.1016/j.livsci.2012.08.013

Koko WS, Galal M, Khalid HS (2000) Fasciolicidal efficacy of Albizia anthelmintica and Balanites aegyptiaca compared with albendazole. J Ethnopharmacol 71:247-252. https://doi.org/10.1016/s0378-8741(00)00172-0

Mannan MA, Masuduzzaman M, Rakib TM, Chowdhury S, Hossain MA (2017) Histopathological and haematological changes in haemonchosis caused by Haemonchus contortus in small ruminants of Bangladesh. Bangladesh J Vet Anim Sci 5:17-23

Meda NT, Lamien-Meda A, Kiendrebeogo M, Lamien CE, Coulibaly AY, MillogoRasolodimby J, Nacoulma OG (2010) In vitro antioxidant, xanthine oxidase and acetylcholinesterase inhibitory activities of Balanites aegyptiaca (L.) Del. (Balanitaceae). Pak J Biol Sci 13:362-368

Mohamed AEH, El-Sayed MA, Mohamed Hegazy E, Helaly SE, Esmail AM, Mohamed NS (2010) Chemical constituents and biological activities of Artemisia herba-alba. Rec Nat Prod 4:1-25

Orengo KO, Maitho T, Mbaria JM, Maingi N, Kitaa JM (2016) In vitro anthelmintic activity of Allium sativum, Allium cepa and Jatropha curcas against Toxocara canis and Ancylostoma caninum. Afr J Pharm Pharmacol 10:465-471. https://doi.org/10.5897/AJPP2016.4551

Parmar D, Chandra D, Prasad A, Singh E, Kaur N, Nasir A (2019) Haemato-biochemical alterations in sheep due to experimentally induced Haemonchus contortus infection. Int J Curr Microbiol Appl Sci 8:2371-2376

Rabel B, Mc Gregor R, Douch PGC (1994) Improved bioassay for estimation of inhibitory effects of ovine gastrointestinal mucus and anthelmintics on nematode larval migration. Int J Parasitol 24:671-676. https://doi.org/10. 1016/0020-7519(94)90119-8

Rhoads ML, Fetterer RH (1995) Developmentally regulated secretion of cathepsin L-Like Cysteine proteases by Haemonchus contortus. J Parasitol 81:505-512

Shalaby H (2013) Anthelmintics resistance: how to overcome it? Iran J Parasitol 8:18-32

Soulsby EJL (1986) Helminthes, arthropods and protozoa of domesticated animals, 7th edn. Bailliere Tindall, London

Tariq KA, Chisti MZ, Ahmed F, Shawl AS (2008) Anthelmintic efficacy of Achillea millifolium against gastrointestinal nematodes of sheep: in vitro and in vivo studies. J Helminthol 82:227-233. https://doi.org/10.1017/S0022 149X08972515

Tariq KA, Chishti MZ, Ahmada F, Shawl AS (2009) Anthelmintic activity of extracts of Artemisia absinthium against ovine nematodes. Vet Parasitol 160:83-88. https://doi.org/10.1016/j.vetpar.2008.10.084

Torres-Acosta JFJ, Molento M, Gives PM (2012) Research and implementation of novel approaches for the control of nematode parasites in Latin America and the Caribbean: is there sufficient incentive for a greater extension effort? Vet Parasitol 186:132-142. https://doi.org/10.1016/j. vetpar.2011.11.053 
Vijigiri D, Sharma PP (2010) Traditional uses of plants in indigenous folklore of nizamabad district, Andhra Pradesh, India. Ethnobotanical Leaflets 2010(1):5. https://opensiuc.lib.siu.edu/ebl/vol2010/iss1/5

Wang GX, Han J, Zhao LW, Jiang DX, Liu YT, Liu XL (2010) Anthelmintic activity of steroidal saponins from Paris polyphylla: phytomedicine. Int J Phytother Phytopharmacol 17:1102-1105. https://doi.org/10.1016/j.phymed. 2010.04.012

Zenebe S, Feyera T, Assefa S (2017) In vitro anthelmintic activity of crude extracts of aerial parts of Cissus quadrangularis L. and leaves of Schinus molle L. against Haemonchus contortus. BioMed Res 2017:1-6. https://doi. org/10.1155/2017/1905987

\section{Publisher's Note}

Springer Nature remains neutral with regard to jurisdictional claims in published maps and institutional affiliations.

\section{Submit your manuscript to a SpringerOpen ${ }^{\odot}$ journal and benefit from:}

- Convenient online submission

- Rigorous peer review

- Open access: articles freely available online

- High visibility within the field

- Retaining the copyright to your article

Submit your next manuscript at springeropen.com 